\title{
THE COVID-19 PANDEMIC: AN ACCELERATOR OF DIGITALISATION IN TOURISM
}

\author{
A.P. PRICOPE (VANCIA) ${ }^{1} \quad$ C.A. BĂLTESCU ${ }^{2}$
}

\begin{abstract}
The aim of this paper is to analyse the effects of the COVID-19 pandemic on leveraging technology to generate new opportunities for travel companies. Tourism is one of the sectors most affected by the Covid-19 pandemic, companies in this sector have never faced such a dramatic situation and their challenge has been to survive and find new ways to generate profit. In this context, the pandemic has become an accelerator of digitalisation and has made digital technologies vital. The study is based on secondary data analysis and the research objectives are to examine the impact of COVID - 19 on travel companies and to highlight the importance of developing digitalisation during the pandemic. To achieve these goals, the authors analysed the actions during the pandemic of the world's largest tour operator, Tui Group.
\end{abstract}

Key words: digitalisation, COVID-19 pandemic, travel companies, Tui Group

\section{Introduction}

Changes in the economic environment affect the whole tourism sector. During times of economic crisis, consumers are forced to bring their patterns of consumption into balance with their incomes and to reconsider their purchasing priorities (Kotler, et al., 2016). Even though after the Global Economic Crisis in 2008-2009, the tourism sector had begun to prosper (UNWTO, 2013), the year 2020 had an unprecedented economic impact on it (UNWTO, 2020a), due to the COVID-19 pandemic. The current COVID-19 crisis has led to economic and health challenges and has had a negative impact on global industries, including the tourism sector, which bears an important significance for the global economy (WTTC, 2020).

This pandemic has had a strong domino effect (Kourentzes, et al., 2021) since all destinations worldwide have imposed travel restrictions to restrain the spread of the virus, and by May 2020, 75\% of them had their borders completely closed (UNWTO, 2020b) for international tourism (Fig.1). Moreover, the tourists' behaviours and their mental wellbeing have been influenced by the pandemic and, as a result, they

\footnotetext{
${ }^{1}$ Transilvania University of Braşov, alina.pricope@unitbv.ro ORCID ID 0000-0001-9774-2825

${ }^{2}$ Transilvania University of Braşov, codruta.baltescu@unitbv.ro ORCID ID 0000-0002-1128-5430
} 
abandoned their travel plans for fear of infection with the disease (Abbas, et al., 2021).

In this context, the travel and tourism sector has been forced to adapt. Although in the recent past, most stakeholders in this sector were concerned with the digitalisation aspect, now, due to the COVID-19 pandemic, this approach is impetuously necessary. The UNWTO secretary general Zurab Pololikashvili believes the industry will change dramatically as a result of the fallout: "The crisis has accelerated digitisation in the tourism value chain, and amplified the adoption of new technologies, while highlighting opportunities for decarbonisation of the sector enhanced by green investments." (FDI Intelligence, 2021).

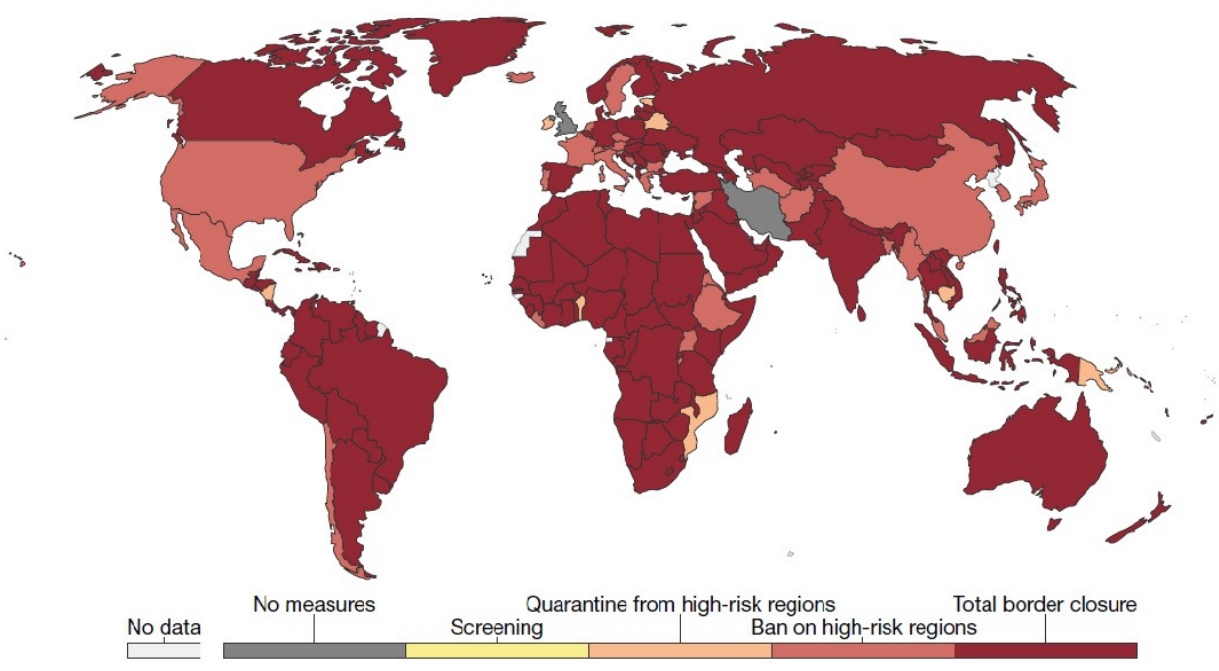

Fig. 1. International Travel Controls During the COVID-19 Pandemic as of May 1, 2020

(Source: Our world in data: https://ourworldindata.org/grapher/international-travel-covid)

The COVID-19 pandemic has shown us that tourism, along with other sectors, can quickly grow digitally: data shows that it has jumped 5 years forward (McKinsey Digital, 2020). The greatest opportunity in tourism is to restart into a new phase, based on sustainability and innovation (UNWTO, 2021), through digitalisation and intelligent use of data. Digitalisation is accelerating with a wide range of technologies being incorporated into new travel concepts, including artificial intelligence (Al), automation, blockchain and the internet of things (IOT), to create a safer, more sustainable and transparent travel experience (Euromonitor International, 2020).

Considering these aspects, the study focuses on the analysis of the effects of pandemic on leveraging technology to generate new opportunities for travel companies.

\section{Literature Review}

Information technology continues to move our society (Xiang, 2018). According to Gartner Glossary (2021) digitalisation "is the use of digital technologies to change a 
business model and provide new revenue and value-producing opportunities". The digitalisation of tourism is influenced by the relationship between access to information on tourism services, the impact information technologies and their online buying and selling process (Saseanu, et al., 2020). Several phases of digitalisation in tourism can be identified as shown Dredge, et al. (2018):

- Phase 1 - sales and marketing: period 1990-2000, the rise of the Internet has enabled organisations and destination businesses in tourism to use technology as a marketing tool. Websites began to replace paper marketing materials, the first online booking systems appeared and distribution systems facilitated increased coordination across the industry.

- Phase 2 - belongs to the period between 2000 to 2010 when the Internet consolidated its position as the main source of information for travellers, and technological progress allowed the creation of a virtual marketplace where products and services can be searched, compared and traded online. The emergence of online travel agencies (OTAs), the "new" intermediaries such as Expedia and Orbitz, which have disturbed the traditional travel agency business model, and the growth of review sites such as TripAdvisor, have given the customer total control over the purchasing process.

- Phase 3 - from 2010, advances such as virtual reality, mobile Apps, social media, wearable technologies, augmented reality have facilitated the interconnection between the digital and physical worlds. All this has contributed towards accelerating the global expansion of tourism businesses.

The phases described above belong to different stages of the Web, from Web 1.0 to Web 3.0. The next stage which has already begun is "The Ultra - Intelligent Web" (Parvathia, et al., 2017). In Web 4.0, the relationship between humans and machines is symbiotic (Congnizant, 2019). In tourism, this relationship is felt particularly strongly. For example, a simple search engine for accommodation in a destination, Web 4.0 technologies allow the websites to suggest all or some of the best options (Tavakoli, et al., 2019).

With the emergence of the Covid-19 pandemic, Web 4.0 has grown steadily, preparing the Internet and the world for Web 5.0. This stage will affect tourism products and services, the hospitality industry, tourists' behaviour, and the business models and various organisations associated with the industry (Duy, et al., 2020).

\section{Methodology}

The aim of the research it to analyse the one of the effects of the COVID-19 pandemic in the tourism sector, namely: the acceleration of the digitalisation process in travel companies.

The objectives of the research are:

- to analyze of the impact of COVID - 19 on travel companies;

- to highlight the importance of the development of digitalisation in tourism businesses in the context of the pandemic.

In order to achieve these objectives, the authors analysed the actions of the world's largest tour operator, Tui Group. The study is based on secondary data analysis and the 
period of research was between 16 and 29 September 2021. The data is mostly collected from Tui Group's official website, from their presentations and speeches at the Annual and Extraordinary General Meetings in 2021 and from online interviews with the company's directors.

Within the framework of the study, some statistical data, available on the Tui Group website, have been processed, determining the context in which the digitalisation theme has been developed.

\section{Did the World's Leading Tourism Group Need Digital Transformation during the Pandemic?}

If we thought digitalisation had reached its peak, it seems that the COVID-19 pandemic has brought new insights into the issue. The big tour operator TUI, although using technology for the efficient operation of its business, realized that pandemic drove an accelerating digital transformation (TechBeacon, 2021).

TUI is the world's leading tourism group. The group's portfolio consists of powerful tour operators, 1,600 leading travel agencies and online portals, five airlines with around 150 aircraft, over 400 hotels, 15 cruise ships and numerous incoming agencies in all major holiday destinations worldwide. It covers the entire tourism value chain under one roof (TUI Group, 2021). However, as the COVID-19 pandemic took hold, operations came to a halt at European tour operator TUI. All their segments were affected, especially the cruise sector due to maintenance costs (Table 1), recording a $98 \%$ drop in business revenue in the third quarter of 2020 compared to the same quarter in 2019.

Quarterly revenue by segment at Tui Group in period 2019-2021

Table 1

\begin{tabular}{|c|c|c|c|c|c|c|c|c|c|c|c|}
\hline In £ milion & $\begin{array}{c}\text { Q1 } \\
\text { FY19 }\end{array}$ & $\begin{array}{c}\text { Q2 } \\
\text { FY19 }\end{array}$ & $\begin{array}{c}\text { Q3 } \\
\text { FY19 }\end{array}$ & $\begin{array}{c}\text { Q4 } \\
\text { FY19 }\end{array}$ & $\begin{array}{c}\text { Q1 } \\
\text { FY20 }\end{array}$ & $\begin{array}{c}\text { Q2 } \\
\text { FY20 }\end{array}$ & $\begin{array}{c}\text { Q3 } \\
\text { FY20 }\end{array}$ & $\begin{array}{c}\text { Q4 } \\
\text { FY20 }\end{array}$ & $\begin{array}{c}\text { Q1 } \\
\text { FY21 }\end{array}$ & $\begin{array}{c}\text { Q2 } \\
\text { FY21 }\end{array}$ & $\begin{array}{c}\text { Q3 } \\
\text { FY21 }\end{array}$ \\
\hline $\begin{array}{c}\text { Hotels \& } \\
\text { Resorts }\end{array}$ & 139.3 & 131.7 & 154.5 & 234.5 & 166.2 & 133.9 & 4.5 & 97.7 & 56.5 & 27.5 & 74.0 \\
\hline Cruises & 190.5 & 234.2 & 256.3 & 284.9 & 238.4 & 243.2 & 2.0 & -11.0 & 0.6 & 1.0 & 1.1 \\
\hline $\begin{array}{c}\text { TUI } \\
\text { Musement }\end{array}$ & 158.3 & 144.5 & 259.4 & 293.9 & 216.7 & 83.7 & -6.2 & 12.1 & 10.5 & 8.1 & 19.0 \\
\hline $\begin{array}{c}\text { Holiday } \\
\text { Experiences }\end{array}$ & 488.1 & 510.4 & 670.2 & 813.4 & 621.4 & 460.8 & 0.2 & 98.9 & 67.5 & 36.5 & 94.1 \\
\hline $\begin{array}{c}\text { Markets \& } \\
\text { Airlines }\end{array}$ & $2,933.8$ & $2,472.4$ & $4,006.8$ & $6,596.4$ & $3,169.8$ & $2,302.2$ & 69.8 & $1,125.7$ & 394.3 & 204.3 & 546.8 \\
\hline $\begin{array}{c}\text { All Other } \\
\text { Segments }\end{array}$ & 153.0 & 118.8 & 68.0 & 96.9 & 59.6 & 24.9 & 1.7 & 8.7 & 6.3 & 7.3 & 8.7 \\
\hline TUl Group & $3,574.8$ & $3,101.6$ & $4,744.9$ & $7,506.6$ & $3,850.8$ & $2,787.9$ & 71.8 & $1,233.3$ & 468.1 & 248.1 & 649.7 \\
\hline
\end{tabular}

(Source: Authors' own elaboration using data available at https://www.tuigroup.com/enen/investors/key-financial-information/key-financial-information-tab )

In this context, Tui Group had to rethink their own strategy, firstly to survive, and then to increase their revenues. With this in mind, at the beginning of the crisis they set three priorities by which they were guided (TechBeacon, 2021): 
1 cost savings - they shut down everything that was not essential for the continuation of the activity and stopped all existing projects. Overall, they managed to reduce the net consumption rate by $70 \%$ in just three months, through good collaboration between the IT and business teams.

2 ensure that their customers could return home - their teams made great efforts to support customers who were on holiday at that time, providing them accurate information and ensuring their safe return home.

3 keep essential systems alive - even if their business was completely shut down, an enterprise of their size had to have some functional systems, such as those capable of dealing with the mass cancellations. Collaboration between IT and business teams was therefore necessary to make the systems as efficient as possible.

As the COVID-19 crisis began to loosen up a bit, Tui Group started to think of new solutions to adapt to the new situation. Invited to an online conference on the topic of digitisation during the pandemic, the $\mathrm{CIO}$ of the TUI Group, Frank Rosenberger said: "When travel does not take place, what are we doing? TUI focused on building futureproof technology and tools. They also looked into how to provide new ways of working, taking into consideration different elements: time management, place, relationships between colleagues and availability of data. In this way, people could work from wherever they were without being tied to the workplace." (DTTT, 2021).

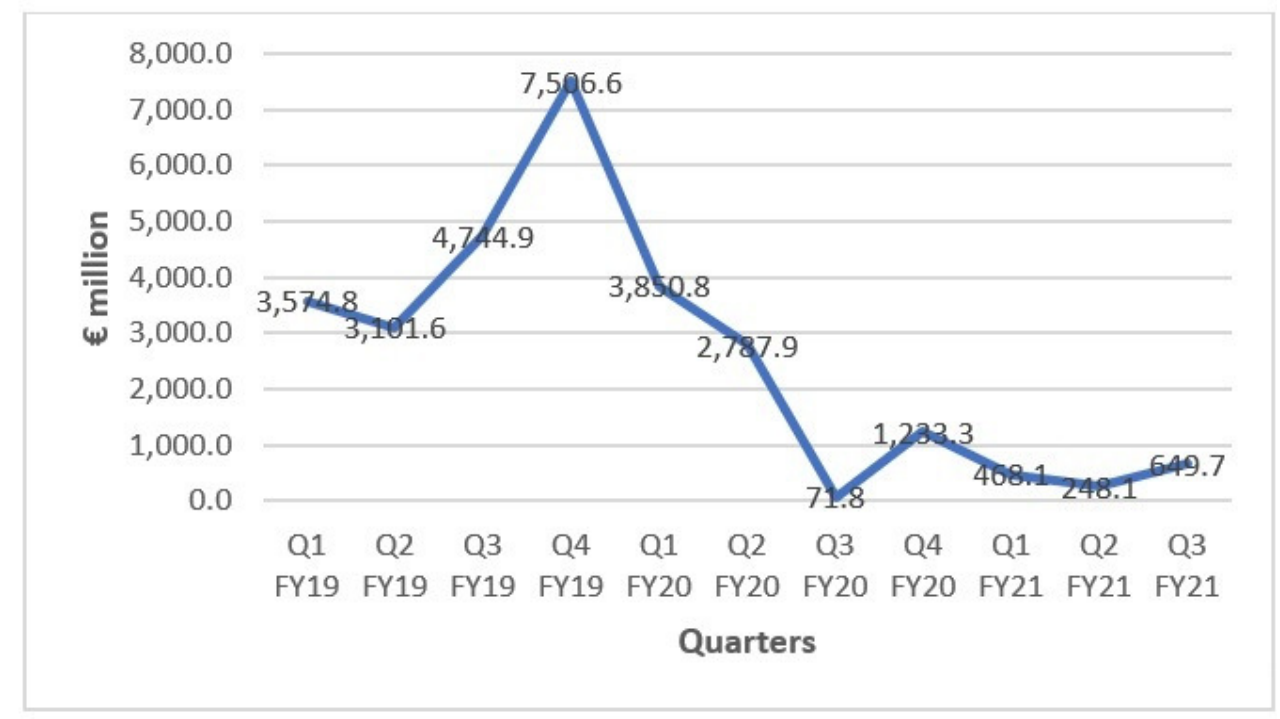

Fig. 2. Evolution of Tui Group's revenue, by quarter from 2019 to 2021. (Source: Authors' own elaboration using data available at https://www.tuigroup.com/enen/investors/key-financial-information/key-financial-information-tab )

Tui Group started since 2018 the transformation from a vertically integrated tourism group to a digital platform company (TUI AGM, 2021) and manages, due to COVID-19 pandemic, to accelerate this process. One of the pillars established in 2018 has already been implemented, namely (TUI AGM, 2021): the transformation of the core reservation 
systems through their own development of TRIPS, which covers all key systems - hotel purchasing, own and third-party room allocation, flights, product packaging, rates and yield, CRM, web frontend and app.

Also, during the pandemic, TUI Group accelerated transformation and growth of its Tours \& Activities platform which form TUI Musement. This platform was previously known as TUI Destination Experiences, which included the independently operated Musement business, but the new TUI Musement creates value for its suppliers and customers by introducing a unique digital platform plus model (Tui Group, 2020) that combines a digital scalable platform with local service delivery in 80 countries worldwide (Musement, 2021). Moreover, thanks to platform scalability, companies like Booking.com, use it for their customers (TUI AGM, 2021).

\section{Conclusions}

The COVID-19 pandemic demonstrates the importance of tourism in the global economy, but also its fragility, exposing the need for digital and sustainable transformation as drivers of recovery.

This study aimed to identify the effects of the Covid-19 pandemic on leveraging technology to generate new opportunities for travel companies. Specifically, this paper focused on the largest stakeholder in the tourism sector, Tui Group, and analysed the actions taken by the company since the beginning of the crisis. Although Tui Group had already started its transformation from a vertically integrated tourism group to a digital platform company, COVID-19 crises forced them to complete this process faster than they had intended.

\section{References}

Abbas, J., Mubben, R., lorember, P., T., Raza, S., Mamirkulova, G., 2021. Exploring the impact of COVID- 19 on tourism: transformational potential and implications for a sustainable recovery of the travel and leisure industry. Current Research in Behavioral Sciences, [e-journal] 2, 100033. https://doi.org/10.1016/j.crbeha.2021.100033

Cognizant, 2019. The Symbiosis of Humans and Machines: Planning for Our Al Augmented Future [pdf] Available at < https://www.cognizant. com/whitepapers/planning-for-our-ai-augmented-future-codex4744.pdf > [Accessed 16 September 2021]

Dredge, D., Phi, G., Mahadevan, R., Meehan, E., Popescu, E.S., 2018. Digitalisation in Tourism. In-depth analysis of challenges and opportunities. Low Value procedure GROSME-17-C-091-A for Executive Agency for Small and Medium-sized Enterprises (EASME) Virtual Tourism Observatory. Aalborg University, Copenhagen, p. 9. [pdf] Available at: <https://ec.europa.eu/docsroom/documents/33163/attachments/1/ translations/en/renditions/native $>$ [Accesed 20 September 2021]

DTTT - Digital Tourism Think Tank, 2021, Digitalisation in times of COVID. [online] Available at < https://www.thinkdigital.travel/opinion/digitalisation-in-times-of-covid/ $>$ [Acceased 17 September 2021] 
Duy, N.T., Mondal, S.R., Van, N.T.T., Dzung, P.T., Minh, D.X.H., Das, S., 2020. A Study on the Role of Web 4.0 and 5.0 in the Sustainable Tourism Ecosystem of Ho Chi Minh City, Vietnam. Sustainability, 12 (17), 7140. https://doi.org/10.3390/su12177140

Euromonitor International, 2020. Rethinking Travel Through Regenerative Tourism and Technology Advancement. [online] Available at $<$ https://www.euromonitor.com/article/rethinking-travel-through-regenerativetourism-and-technology-advancement $>$ [Accesed 22 September 2021]

FDI Intelligence, 2021. Pandemic causes tourism investment to plummet. [online] Available <https://www.fdiintelligence.com/article/80019?trfcsrc=_ext_SEM_GA_!!!\&cid=140 76309798\&agid $=128084729649$ \&adid=536386313173\&gclid=EAlalQobChMlwvCOltm B8wIV9pJmAh2boQWSEAAYASAAEgJk-PD_BwE > [Accessed 20 September 2021]

Gartner Glossary. [online] Available at < https://www.gartner.com/en/informationtechnology/glossary/digitalization $>$ [Accessed 20 September 2021]

Kotler, P., Bowen, J., T., Makens, J., C., Baloglu, S., 2016. Marketing for Hospitality and Tourism: 7th Edition, Editura Pearson Education.

Kourentzes, N., Saayman, A., Jean-Pierre, P., Provenzano, D., Sahli, M., Seetaram, N., Volo, S., 2021. Visitor arrivals forecasts amid COVID-19: A perspective from the Africa team. Annals of Tourism Research, 88, 103197. https://doi.org/10.1016/j.annals.2021.103197

McMinsey, 2020. The COVID-19 recovery will be digital: A plan for the first 90 days. [online] Available at < https://www.mckinsey.com/business-functions/mckinseydigital/our-insights/the-covid-19-recovery-will-be-digital-a-plan-for-the-first-90-days > [Accessed 21 September 2021]

Musement, 2021. The company [online] Available at < https://www.musement.com/us/about-us-2-p/ > [Accessed 29 September 2021]

Parvathia, M., Mariselvi, R., 2017. A bird's eye on the evolution - Web 1.0 to Web 5.0: Lib 1.0 to Lib 5.0. International Journal of Advance Research Trends in Engineering and Technology, [e-journal] 4(4), pp.167-176. Available through IJARTET website $<$ http://www.ijartet.com/ >

Saseanu, A.S., Ghita, S.I., Albastroiu, I. and Stoian, C.-A., 2020. Aspects of Digitalization and Related Impact on Green Tourism in European Countries. Information, 11(11), 507. http://dx.doi.org/10.3390/info11110507

TechBeacon, 2021. How the pandemic drove digital transformation at TUI. [online] Available at < https://techbeacon.com/app-dev-testing/how-pandemic-drove-digitaltransformation-tui $>$ [Accessed 21 September 2021]

The World Travel \& Tourism Council, 2021. Travel \& Tourism Economic Impact 2021. Global Economic Impact and Trends 2021. [online] Available at <https://wttc.org/Portals/0/Documents/Reports/2021/Global\%20Economic\%20Impac t\%20and\%20Trends\%202021.pdf?ver=2021-07-01-114957-177 >[Accessed 16 September 2021]

TUI AGM, 2021. Speech Friedrich Joussen Chairman of the Executive Board of TUI AG on the occasion of the Annual General Meeting on 25 March 2021 [pdf]. Available at < https://www.tuigroup.com/damfiles/default/tuigroup-15/de/medien/sonderseite-hv- 
2021/Redetext-Friedrich-Joussen-zur-HV-2021_V6.4_EN.pdf-

9f75680f3d202fbf68d420fc8f18a22f.pdf > [Accessed 27 September 2021]

Tui Group, 2020. TUI Group accelerates transformation and growth of its Tours \& Activities platform. [online] Available at < https://www.tuigroup.com/en-en/media/ press-releases/2020/2020-09-28-tui-group-accelerates-transformation-and-growth-oftours-activities-platform > [Accessed 29 September 2021]

Tui Group, 2021. About TUI Group. [online] Available at < https://www.tuigroup.com/en-en/about-us/about-tui-group > [Accessed 17 September 2021]

World Tourism Organization (UNWTO), 2020a. Restrictions on tourism travel starting to ease but caution remains, UNWTO Reports. [online] Available at <https://www.unwto.org/news/covid-19-restrictions-on-tourism-travel >[Accessed 16 September 2021]

World Tourism Organization (UNWTO), 2020b. Tourism and covid-19 - unprecedented economic impacts [online] Available at < https://www.unwto.org/tourism-and-covid19-unprecedented-economic-impact $>$ [Accessed 16 September 2021]

World Tourism Organization (UNWTO) 2021, Digital tools to revitalize tourism. [online] Available at <https://www.unwto.org/news/digital-tools-to-revitalize-tourism> [Accessed 21 September 2021]

World Tourism Organization (UNWTO) and International Labour Organization (ILO), 2013. Economic Crisis, International Tourism Decline and its Impact on the Poor [pdf] Available at < https://www.e-unwto.org/doi/epdf/10.18111/9789284414444 > [Accessed 16 September 2021]

Xiang, Z., 2018. From digitization to the age of acceleration: On information technology and tourism. Tourism Management Perspectives, 25, pp. 147-150. https://doi.org/10.1016/j.tmp.2017.11.023 